Innlegg på inntil $\mathbf{4 0 0}$ ord lastes opp i http://mc.manuscriptcentral.com/tidsskriftet.

Redaksjonen forbeholder seg retten til å foreta redaksjonelle endringer.

Forfattere av vitenskapelige artikler har tilsvarsrett (jf. Vancouver-gruppens regler).

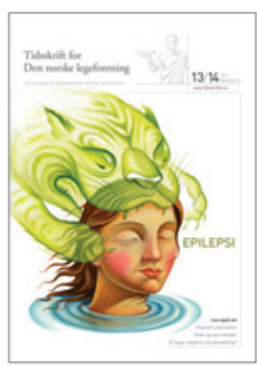

\section{Hvilke prøver er best til påvisning av Chlamydia trachomatis?}

I Tidsskriftet nr. 13/2011 drøfter Harald Moi hvilke prøvematerialer som egner seg best for påvisning av Chlamydia trachomatis (1). Moi anbefaler ikke urinprøver fra kvinner pga. lavere sensitivitet enn selvtatt vaginalpinne (1). Dette har ført til mange reaksjoner fra våre rekvirenter som spør om de ikke lenger kan sende urinprøver fra kvinner til chlamydiaundersøkelse.

Socialstyrelsen i Sverige anbefaler selvtatt vaginalpinne, som har like god eller noe bedre sensitivitet enn cervixprøve (2), blant annet basert på to norske studier $(3,4)$. I studien fra Bergen hvor man benyttet en screeningtest basert på SDA (Strand Displacement Amplification)-prinsippet, var sensitiviteten for urinprøver 90,2\% (3), mens den i studien fra Trondheim, som benyttet polymerasekjedereaksjon (PCR), var $95,5 \%$ (4). Det er imidlertid vanskelig å sammenlikne ulike studier da forutsetningene for beregning av sensitivitet ofte er forskjellig, og testenes analytiske sensitivitet er avhengig av hvilken nukleinsyreekstraksjonsmetode og testprinsipp som benyttes.

Ved Avdeling for medisinsk mikrobiologi, St. Olavs hospital har prosentandelen av urinprøver fra kvinner i årene 2008-10 ligget på litt over $30 \%$. I 2008 mottok vi 5402 urinprøver og 9856 penselprøver fra kvinner til chlamydiatesting. For kvinner $\leq 25$ år var andelen positive prøver fra urin $14,9 \%$, mot $9,9 \%$ for penselprøver. For kvinner $>25$ år var de respektive tallene henholdsvis 5,7\% og 2,9\%. Grunnen til at urinprøvene fanger opp så mange chlamydiainfeksjoner i forhold til penselprøvene vet vi ikke sikkert, men en forklaring kan være at det oftest er pasienter med symptomer som avgir urinprøve, mens store deler av penselprøvene er screeningprøver fra pasienter uten symptomer.

Studien fra Trondheim omfattet friske, seksuelt aktive, ikke-gravide kvinner i alderen 16-24 år (4). Prevalensen av chlamydiainfeksjoner var $4,1 \%$, og sensitiviteten på 95,5\% var den samme for selvtatte urinprøver som for prøver tatt av lege fra introitus. Vår erfaring tilsier derfor at korrekt tatt urinprøve hos kvinner fortsatt kan være et alternativ for kvinner som vegrer seg for å gjennomgå gynekologisk undersøkelse eller ta vaginalprøve selv, og at det av den grunn ikke bør frarådes å ta denne type prøver. Det er imidlertid viktig å gi instruksjon om at det kun er den første urinporsjonen som skal benyttes til chlamydiatesting. Ved negativt resultat og fortsatte symptomer anbefales ny prøve. Det kan da være aktuelt å be om påvisning av Mycoplasma genitalium i samme prøve.

\section{Svein Arne Nordbø}

Avdeling for medisinsk mikrobiolog

St. Olavs hospital

Svein Arne Nordbø (f. 1952) er overlege ved Avdeling for medisinsk mikrobiologi, St. Olavs hospital.

Ingen oppgitte interessekonflikter.

\section{Litteratur}

1. Moi H. Hvilken prøve er best for å påvise genital chlamydiainfeksjon? Tidsskr Nor Legeforen 2011 131: 1279.

2. Urinprov vid diagnostik av klamydia hos kvinnor. SBU Alert-rapport nr. 2010-05. Stockholm: Socialstyrelsen, 2010. www.sbu.se/upload/ Publikationer/Content0/3/

Urinprov klamydia kvinnor 201005.pdf (2.6.2011).

3. Haugland $S$, Thune T, Fosse $B$ et al. Comparing urine samples and cervical swabs for Chlamydia testing in a female population by means of Strand Displacement Assay (SDA). BMC Women's Health 2010; 10: 9.

4. Bakken IJ, Bratt H, Skjeldestad FE et al. Påvisning av Chlamydia trachomatis i urin-, vulva- og cervix prøver. Tidsskr Nor Lægeforen 2005; 125 : $1629-30$

\section{Kreftutredning}

Jeg takker Anne Tollan for hennes kommentar i Tidsskriftet nr. 19/2011 (1). Jeg er enig $i$ at det burde vært med et punkt om malignitetssuspekte vaginalblødninger i mitt forslag til tilstander som indikerer hasteutredning. Jeg hadde også med et punkt om postmenopausale blødninger, men fant ut at det ble for ufullstendig og tok det ut, ettersom mitt innlegg først og fremst var rettet til sykehusene som mottakere av henvisningen. Det er svikten i dette leddet som opprører pasientene mest, og det er i dette leddet 48-timersregelen bør gjelde. For å dekke det behovet som Anne Tollan etterlyser, vil jeg foreslå rett og slett «Cancersuspekte vaginalblødninger». Dermed skulle også det kjønnsdiskriminerende aspektet, som jeg for øvrig finner svært søkt, være ryddet av veien.

Sølve Hognestad

Hafrsfjord

Sølve Olav Hognestad (f. 1932) er tidligere avdelingsoverlege ved Øre-, nese-. halsavdelingen, Sentralsjukehuset i Rogaland (1978-2000), nå pensjonist.

Ingen oppgitte interessekonflikter.

Litteratur

1. Tollan A. Vaginalblødning også faresignal. Tidsskr Nor Legeforen 2011; 131: 1873.

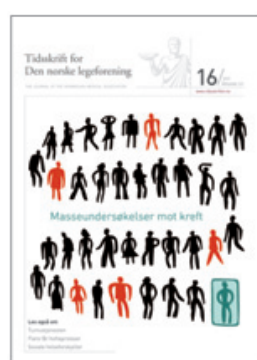

\section{Kryptogent om cerebrale arterielle karspasmer}

I Tidsskriftet nr. 16/2011 mener Marte Helene Bjørk og medarbeidere å illustrere reversible cerebrale karspasmer komplisert av hjerneslag hos «en person i 20-årene med kjent migrene med aura» (1).

Reversibelt cerebralt vasokonstriksjonssyndrom er en heterogen tilstand, karakterisert av tordenskrallhodepine og multiple segmentale cerebrale arterielle innsnevringer på angiografi (reverseres i løpet av dager til uker), som kan kompliseres av hjerneslag og en sjelden gang død. Infarkter etableres gjerne bilateralt og i vannskilleomåder. Tidsforløpet av karspasmene og komplikasjonene taler for en dynamisk prosess. Subaraknoidalblødning, vaskulitt og hypertensiv krise må alltid mistenkes. En rekke forhold som nevrokirurgiske inngrep, bruk av sympatomimetika og migrenemidler kan også utløse karspasmer. Assosia- 